\title{
TECHNOLOGY-ASSISTED SUPPLEMENTAL WORK: CONSTRUCT DEFINITION AND A RESEARCH FRAMEWORK
}

\section{Grant H. Fenner and Robert W. Renn}

Extending the workday to the home into the night and weekends is nothing new; however, the wide array of technological tools that facilitate an anytime-anywhere connectedness of employees to their employers is a recent phenomenon. Technology-assisted supplemental work (TASW) is the practice of lengthening working time by remaining connected to work, coworkers, supervisors, and other organizational stakeholders from home via advanced digital information technology (i.e., personal and handheld computers, cellular phones, or pagers). Although previous research offers insight into some aspects of this work form (Venkatesh E Vitalari, 1992), we present a new, broader theoretical framework that explains how organizational climate and employee characteristics promote the performance of TASW, and how both perceived usefulness of technology and satisfaction with adopted technology affect the strength of these relationships. We also explain the linkages among TASW and job performance, career success, and work-tofamily conflict and incorporate media richness and time and boundary management as moderators of these relationships. We present propositions, offer a general research strategy, and discuss the framework's theoretical and managerial implications. (C) 2004 Wiley Periodicals, Inc.

\section{Introduction}

Rapid advances in technology are redefining jobs by making it easier and more affordable for organizations to equip employees with technology capable of extending normal working hours beyond the traditional workplace and into the home (Boyd, 1997; Carey, 1996; King, 1998). When full-time employees work at home after regular working hours at night or on weekends, they perform supplemental work. Supplemental work is a form of distributed or remote work where employees engage in job-related activities at home and away from the traditional workplace (Venkatesh \& Vitalari, 1992). The present article is concerned with technology-assisted supplemental work (TASW), which we define as the performance of roleprescribed job tasks by full-time employees with the aid of advanced information and telecommunications technology at home or when away from home while on holiday.

Managers and professionals are committing more time than in the past to supplemental work and adopting the use of tech-

Correspondence to: Grant H. Fenner, Arkansas State University, College of Business, Jonesboro, AR 72467, e-mail: gfenner@midsouth.rr.com

Human Resource Management, Summer/Fall 2004, Vol. 43, Nos. 2 \& 3, Pp. 179-200

(c) 2004 Wiley Periodicals, Inc. Published online in Wiley InterScience (www.interscience.wiley.com).

DOI: $10.1002 / \mathrm{hrm} .20014$ 
In 2001, nearly

11 million

Americans performed, on average, seven hours of job-related work per week at home without a formal compensation agreement. nological tools as a means of accomplishing it. In 2001 , nearly 11 million Americans performed, on average, seven hours of job-related work per week at home without a formal compensation agreement (United States Department of Labor, 2002). Most of the people who performed this extra-work activity were managers or professionals, with $79.6 \%$ indicating that they relied upon a computer or cell phone in their work at home. Fifty-seven percent of the workers performing unpaid job-related work at home identified "finishing or catching up on their work" as its leading cause, with an additional $31 \%$ of those surveyed reporting that it was "the nature of the job" (United States Department of Labor, 2002). Other studies suggest that portability of tasks, availability of telecommunications links, and commuting time contribute to the performance of supplemental work (Venkatesh \& Vitalari, 1992).

Although employees are performing TASW with a variety of versatile advanced information technologies, the impact of this form of work on job performance, career success, and work-to-family conflict remains a point of debate (Boyd, 1997; Carey, 1996; "Do Laptops and LANS Translate into Longer Hours?", 1998; King, 1998). Empirical research suggests employees who engage in TASW in the privacy of their home have the potential to outperform those who avoid working at home after regular hours because of reduced work interruptions and greater autonomy (Venkatesh \& Vitalari, 1992). However, even some employees who engage in TASW may not outperform their coworkers because of the types of digital information technology they use, types of tasks they perform, inability to work without structure, feelings of isolation, and interruptions from family members and friends (Allen, Renn, \& Griffeth, 2003). A study by Galinsky, Kim, and Bond (2001) also reveals that workers using advanced information technology to perform supplemental work frequently express complaints of feeling overworked.

Inconsistencies in studies of the impact of TASW on work outcomes may rest with the scarce attention given to factors that affect the strength and direction of the relationships between TASW and work outcomes. As one example, the relationship between TASW and job performance and career success may depend on the media richness of adopted technologies and the types of tasks performed with this technology (Daft \& Lengel, 1984, 1988). As another example, the impact of TASW on work-to-family conflict may vary with the employee's time- and boundarymanagement skills (Ashforth, Kreiner, \& Fugate, 2000; Macan, 1994). Drawing from recent theoretical and empirical work, there is reason to believe that employees who perform TASW and who are more effective at managing time and boundaries may experience less work-to-family conflict than those unable to manage time and work and home boundaries (Ashforth et al., 2000).

Besides a need to clarify the outcomes of TASW, researchers have made relatively little progress in identifying individual-level and organization-level antecedents of this form of work (Venkatesh \& Vitalari, 1992). Research linking individual differences to information technology (IT) use experienced a decline in the 1980s, only to enjoy renewed interest in the 1990s and early 2000s (Agarwal \& Prasad, 1998; Huber, 1983; Leonard-Barton \& Deschamps, 1988; Thatcher \& Perrewe, 2002). Following this recent trend, we feel that revisiting the predictive capacity of individual-level characteristics (e.g., job involvement, conscientiousness, career commitment, and personal innovation) holds much promise for explaining which employees will be more likely than others to perform TASW. With respect to organization-level antecedents, we suggest that organizational climate plays an important role in explaining the amount of TASW employees perform.

Figures 1 and 2 depict the proposed relationships among the identified constructs. Broadly speaking, Figure 1 proposes that the antecedents of TASW are (1) an organization's climate for TASW and (2) four employee characteristics: personal innovativeness, job involvement, conscientiousness, and career commitment. The model includes perceived usefulness of technology and satisfaction with adopted technology as moderators capable of influencing the strength of the relationships between the predictor constructs and TASW. Figure 2 proposes that TASW is related to 


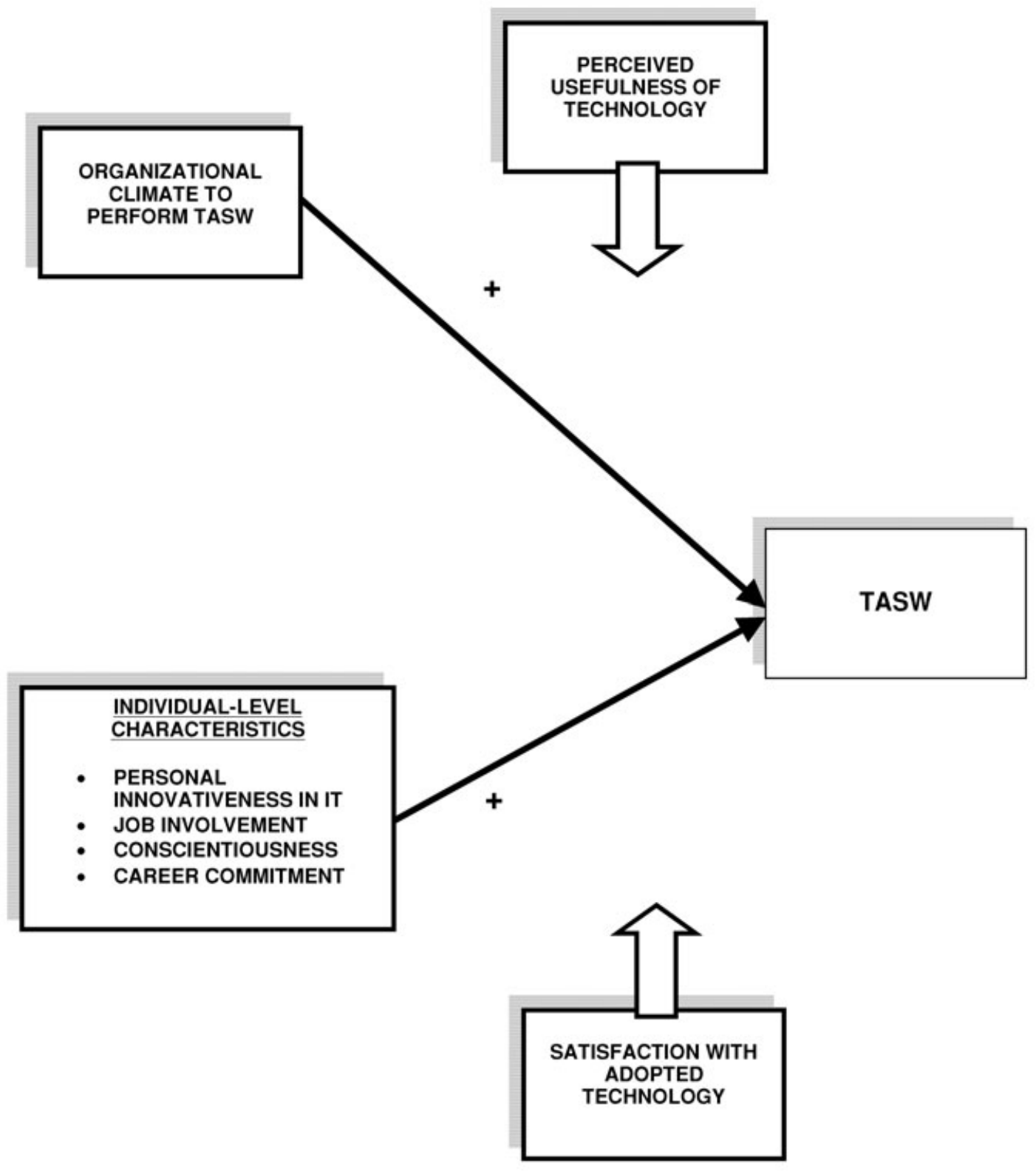

Figure 1. Proposed Antecedent and Moderator Relationships Promoting TASW as the Outcome.

performance and career success, but that the strength of this relationship will be influenced by the media richness of the technological tools selected and task routineness. In addition, Figure 2 shows that TASW is an antecedent of work-to-family conflict and that this relationship is moderated by both timeand boundary-management skills. In the next sections, we develop the TASW construct and relate it to the proposed antecedents, consequences, and moderators.

\section{TECHNOLOGY-ASSISTED SUPPLEMENTAL WORK}

When workers lengthen their working time by performing role-prescribed tasks for their full-time employer by remaining connected to their work, coworkers, supervisors, or other organizational stakeholders, from home or away from work when on holiday, by means of digitized technology, then they are engaging in TASW. Technology-assisted sup- 


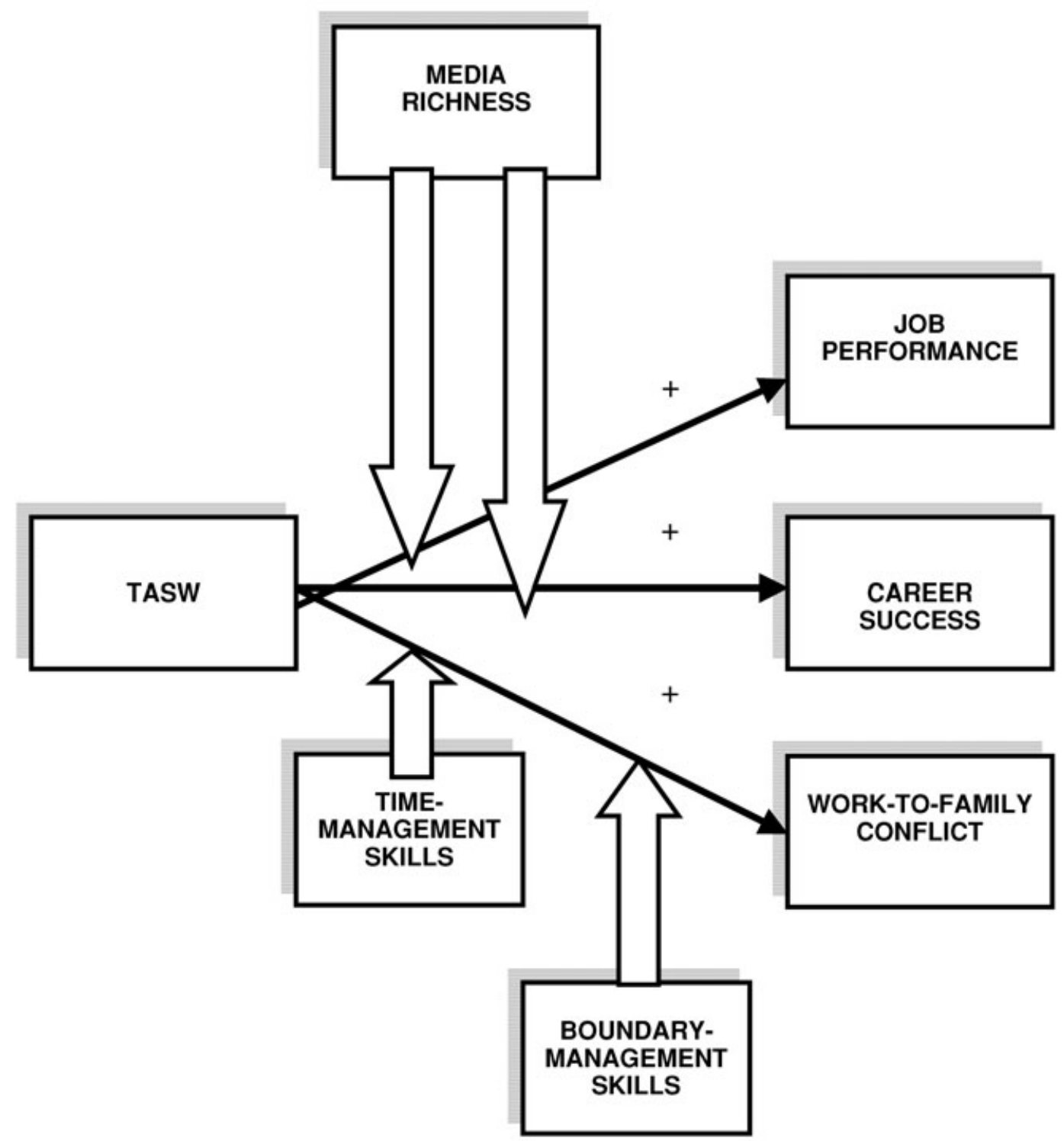

Figure 2. Proposed Outcome and Moderator Relationships of TASW as the Antecedent.

plemental work relies upon the use of technological tools like computers, e-mail, or the use of devices as basic and portable as cell phones to make after-hours work more efficient. The distinction between normal working hours, after-hours work, and extending one's workday or workweek becomes fuzzier as managers and professional employees progress up the organizational hierarchy. Therefore, we suggest "normal working hours" to constitute a minimum of 40 hours in a central work environment and that these "normal working hours" terminate once an employee's supervisors and cohorts begin departing the central location for their home or other nonjob functions at the end of a customary working period.

We distinguish TASW from other forms of distributed work in Table I. Technologyassisted supplemental work is in-role behavior defined by Van Dyne, Cummings, and Parks (1995) as "behavior that is required or 
TABLE I Comparison of TASW to Other Distributed Work Forms

\begin{tabular}{|c|c|c|c|c|c|c|}
\hline & TASW & $\begin{array}{c}\text { Supplemental } \\
\text { Work }\end{array}$ & $\begin{array}{l}\text { Remote } \\
\text { Work }\end{array}$ & Telecommuting & $\begin{array}{l}\text { Virtual } \\
\text { Work }\end{array}$ & $\begin{array}{c}\text { Work at } \\
\text { Home }\end{array}$ \\
\hline $\begin{array}{l}\text { In-Role } \\
\text { Behavior }\end{array}$ & Always & Always & Usually & Usually & Usually & Usually \\
\hline $\begin{array}{l}\text { Represents } \\
\text { After, Extra, } \\
\text { and/or Catch- } \\
\text { up Work }\end{array}$ & Always & Always & Sometimes & Sometimes & Sometimes & Sometimes \\
\hline $\begin{array}{l}\text { Technologically } \\
\text { Connected }\end{array}$ & Always & Sometimes & Sometimes & Always & Always & Sometimes \\
\hline $\begin{array}{l}\text { Performs } \\
\text { Portable Tasks }\end{array}$ & Always & Always & Sometimes & Always & Always & Sometimes \\
\hline $\begin{array}{l}\text { Formalized } \\
\text { Structure }\end{array}$ & No & No & Sometimes & Always & Sometimes & Sometimes \\
\hline $\begin{array}{l}\text { Full-Time } \\
\text { Employee of } \\
\text { an Organization }\end{array}$ & Always & Always & Always & Sometimes & Sometimes & Sometimes \\
\hline
\end{tabular}

Definitions:

TASW - the prescribed performance of job-related tasks by full-time workers at home, after normal work hours, or on weekends facilitated by the use of technological tools.

Supplemental Work-the performance of job-related tasks by full-time workers at home, after normal work hours, or on weekends (Venkatesh \& Vitalari, 1992).

Remote Work-a work environment where a worker is physically separated from his or her manager (Staples, 2001).

Telecommuting - a work environment where information technology capabilities become a substitution for a worker's presence at a central work location (Stevens \& Szajna, 1998).

Virtual Work-a work environment where information technology capabilities provide workers the ability to conduct work "anywhere-anytime" (Galinsky, 1992).

Work at Home - all work performed at home, regardless of whether one is an employee or self-employed (Kraut, 1989).

expected as part of performing the duties and responsibilities of the assigned role" (p. 222). It represents extra and/or catch-up work by an organization's full-time employees who are technologically connected to organizational stakeholders and who perform tasks that are portable and informally structured.

Supplemental work, as defined by Venkatesh and Vitalari (1992), is broadly described as the performance of job-related tasks at home after hours and may include the use of technology. However, it may also include tasks that are not technologically related, such as composing presentations by hand or reading hard copy of business-related materials.

Technology-assisted supplemental work is similar to supplemental work, telecommuting, virtual work, and work at home, since they all represent forms of remote work. Remote work is a general description of work performed where the worker is physically separated from one's supervisor (Staples, 2001). Unlike TASW, telecommuting amounts to remote work where one spends a portion of one's workweek or every workday working from home or a satellite office where technology is used as a surrogate for one's presence in a central work environment, as opposed to simply extending one's workday at home.

Virtual work best describes the dimension of work that technology offers to workers, enabling them to remain connected "anywhere-anytime" regardless of whether they are at home, in their car, in an airport terminal, performing jobs that are full-time or part-time, working for an employer, or 
This anytimeanywhere connectedness of employees to their work, coworkers, supervisors, customers, and other organizational stakeholders with modern technologies blurs the traditional boundaries that have customarily separated work from family and has changed the meaning of being at home. working for oneself (Galinsky, 1992). Lastly, work at home describes any work that is performed at home regardless of whether one is an employee of an organization or working in a self-employed position, such as that performed by a consultant or sales agent representing products from more than one firm (Kraut, 1989).

Distinguishing TASW from common supplemental work rests with the role played by technology in redefining how work is being performed in contemporary organizations. Today's workers have ready access to technology that is capable of accessing file drawers of information, downloading a set of complex engineering drawings, communicating with several coworkers simultaneously, or accessing an annual operating budget from the department level to that of the entire organization while seated in one's study or family room (Gordon, 2001).

Concurrently, employers in an increasingly competitive global marketplace count on their managers and professional employees to work more than 40 hours per week and are prepared to equip them with an array of technological tools and directly or indirectly link rewards, promotions, and other incentives for work performance that can only be delivered by means of supplemental work (Higgins, Duxbury, \& Irving, 1992; Venkatesh \& Vitalari, 1992). This anytime-anywhere connectedness of employees to their work, coworkers, supervisors, customers, and other organizational stakeholders with modern technologies blurs the traditional boundaries that have customarily separated work from family and has changed the meaning of being at home (Galinsky et al., 2001; Marsan, 2001; O'Mahony \& Barley, 1999).

\section{ORGANIZATIONAL CLIMATE, INDIVIDUAL DIFFERENCES, AND TASW}

\section{Organizational Climate for TASW}

According to Barclay, Higgins, and Thompson (1995) and Mathieson (1991), employee usage of technological tools such as IT systems is influenced by both the presence of social forces and control factors within the work environment. Social forces refer to the existence of behavioral norms within the work environment driven by explicit and implied pressures exerted by supervisors, coworkers, and subordinates to use technology such as an IT system. Jones, Sundaram, and Chin (2002) compare the presence of control factors in an organization's environment to the degree and scope of organizational support offered to employees in light of their use of technology. It is our contention that organizational climate is a parsimonious surrogate for the social and control factors described above as having a significant relationship with IT usage behavior.

Organizational climate, which is a global construct defined as a shared perspective held by organizational members concerning the critical elements of their organization, is influenced by management and, in turn, serves to guide their actions on the job (Kopelman, Brief, \& Guzzo, 1990; Ostroff \& Schmitt, 1993; West, Smith, Lu Feng, \& Lawthom, 1998). Because a variety of climates exist at any one time within an organization, department, work group, or team, climate is best described as being focused on a specific activity or referent such as a climate for service, quality, success, or, in this analysis, an organization's climate to perform TASW (Schneider, Gunnarson, \& Niles-Jolly, 1994, as cited in Schneider, White, \& Paul, 1998).

Schneider and Rentsch (1988), as cited in Kopelman et al. (1990), suggest that an organization's climate shapes the attitudes of its members toward organizational policies, practices, and procedures by the manner in which it supports and rewards compliant behavior. According to Kopelman et al. (1990), the dimensions of an organization's climate that influence the actions of employees are embedded in the (1) organization's goals, (2) methods advocated by the organization to perform one's job, (3) degree to which an employee feels organizational rewards are aligned with job performance, (4) employee perceptions that they are being provided the necessary resources by the organization to do their jobs, and (5) employee feelings of the consideration believed to be extended by the organization to themselves and their coworkers. 
Figure 1 depicts the influence that an organization's climate for TASW has on the likelihood that its employees will engage in this extra-work activity. For instance, goals emphasized by the organization provide clarity to the employee regarding the outcomes that are expected of him or her (Kopelman et al., 1990). As an example, performance management prescribes a relationship between superior and subordinate based upon (1) describing key results important to the organization, (2) establishing individual goals or objectives, (3) identifying how achievement of these objectives will be measured, (4) providing performance feedback, and (5) rewarding achievement to further shape employee attitudes and work behaviors (Taylor \& Pierce, 1999).

Organizations that encourage managers and their subordinates to cooperate in developing goals consistent with organizational priorities combined with appraisal systems that monitor and reward employee achievement of objectives are more likely to experience improved employee morale and performance (McAfee \& Champagne, 1993). Goals help focus employee efforts toward critical activities, promote the exertion of greater effort, contribute to the worker's development of strategies to achieve established goals, and instill worker persistence in achieving these goals (Locke, Shaw, Saari, \& Latham, 1981). We argue that organizations adhering to performance-management strategies will emphasize individual-level goals stressing behaviors important in achieving corporate-level objectives. For example, an organization may promote quick response goals to customer demands that, in turn, motivate employees to remain connected to work after normal working hours and, thus, promote TASW.

Operating procedures may also motivate performance of TASW. Acceptable job behaviors are promoted informally by the activities of coworkers and formally through communications tendered by supervisors or by organizational policies and procedures. Louis (1990) suggests that role theory (Mortimer \& Simmons, 1978) accounts for the impact that informal organizational procedures have on an organization's workforce by the manner in which newly introduced employees model the behavior of coworkers, senior colleagues, mentors, and credible supervisors. These role models identify the work attitudes/behaviors most appropriate for new entrants to imitate if they wish to fit in.

Furthermore, Rousseau (1990) suggests that the behavioral norms encouraging employees to work hard or to work longer hours will be driven by an organization's espoused values communicated by supervisors, coworkers, and the organization itself. These values, according to Rousseau, are "the preferred states often manifested in observable behaviors" (p. 159). Some organizations adopt a harder working climate where longer working hours is an advocated value encouraged by the statements made by supervisors or coworkers, or by the manner in which formal work procedures describe expected work behaviors. As an example, company policy may require employees who are issued a company cell phone to answer calls regardless of the time or day of the week.

Rewards or incentives play a critical role in motivating employees to perform TASW. Drawing from Kopelman et al. (1990), if an employee sees his or her coworkers who engage in TASW being promoted more quickly, receiving better raises, offered more favorable job responsibilities, or recognized by the organization for their supplemental work habits, it is plausible that they too will engage in similar work behaviors to the extent that these rewards are valued by the employee. This rationale is supported by reinforcement theory, which suggests individuals who are rewarded for certain behaviors will be more inclined to draw a relationship between the behaviors and the rewards and, thus, more apt to repeat those behaviors (Skinner, 1969). In addition, expectancy theory suggests that the more the employee perceives his or her efforts will produce certain outcomes, and the greater the value they associate with the rewards received for those outcomes, then the greater their motivation will be to engage in that activity (Vroom, 1964).

Employees' beliefs that their organization offers them the technological tools necessary to perform their job tasks are ex-

\author{
Operating \\ procedures may \\ also motivate \\ performance \\ of TASW. \\ Acceptable \\ job behaviors \\ are promoted \\ informally by \\ the activities \\ of coworkers \\ and formally \\ through \\ communications \\ tendered by \\ supervisors or by \\ organizational \\ policies and \\ procedures.
}


Personal innovativeness in information technology (PITT) is also described as a stable and situationspecific trait that encourages those who rank high in this characteristic to respond in a predictable manner toward focused behaviors such as the use of technological tools in one's work. pected to be positively associated with the performance of TASW. Drawing on perceived organizational support theory (POS), employees who sense their organization cares about them and is willing and able to provide them with the tools necessary to perform their jobs are expected, in turn, to offer increased levels of commitment to the organization in carrying out their job responsibilities and in expressing involvement in their organization (Hutchison, Sowa, Eisenberger, \& Huntington, 1986). The list of necessary tools includes hardware as well as the organizational training to effectively use this hardware and/or the critical service support important in resolving hardware or related software problems. Our model suggests employees who receive technological tools such as laptop computers or cell phones from their employers will more likely view this as an example of the organization's support for their work and, in turn, express greater willingness to use these technological tools in the performance of supplemental work at home.

Lastly, Kopelman et al. (1990) maintains the importance of socioemotional support as a final dimension of organizational climate that affects the perceived value of work outcomes. The authors suggest that an organization that is considered by its workers to give their general welfare greater credence through the actions of senior management and supervision will, with time, be held in higher esteem by the workers. The POS literature suggests that employees with favorable perceptions of the exchange relationship with their supervisors or organizations tend to experience more positive work attitudes and performance (Shore \& Tetrick, 1991; Wayne, Shore, \& Liden, 1997). This higher regard for the organization's managers and supervisors by employees translates into an attachment of greater relevance to the rewards these organizational leaders offer. The enhanced value of the reward results in greater motivation by the employee to earn that reward by applying efforts to job tasks deemed achievable by the employee and acceptable by the organization, such as engaging in TASW.
Proposition 1: Climate to perform TASW will be positively related to TASW.

Employee Characteristics and TASW

Personal Innovativeness in Information Technology. This is an individual-level construct that describes a person's motivation or heightened interest in experimenting with and using new and various forms of IT as a technological tool and helps to address the question: Why are some employees quick to adopt new technologies while others rebuff them (Agarwal \& Prasad, 1998)? This is an important predictor construct, because it holds the potential of identifying employees who are more or less likely to adopt the use of new technological tools in their work.

Personal innovativeness in information technology (PITT) is also described as a stable and situation-specific trait that encourages those who rank high in this characteristic to respond in a predictable manner toward focused behaviors such as the use of technological tools in one's work (Thatcher \& Perrewe, 2002). These characteristics are essential because much of the research in IT deals with testing the relationships between antecedents and intentions. Jones et al. (2002) found a significant and direct positive effect between personal innovativeness and the infusion or extent to which the salespeople studied described the spread of employee use of salesforce automation systems. We propose that a similar relationship is present with PITT and the performance of TASW. Specifically, we predict that a positive relationship exists between the strength of workers' PITT and their willingness to use technology in the performance of supplemental work.

Job Involvement. High job-involvement employees purposely identify with their jobs because of the job's unique ability to satisfy their most important intrinsic and extrinsic needs (Kanungo, 1982). Job involvement is an individual-level characteristic based upon an employee's level of self-esteem and internal work motivation and needs, which are satisfied and influenced by situational characteristics of the job (Brown, 1996; Igbaria, Parasuraman, \& Badawy, 1994; Kanungo, 1982). Highly job- 
involved employees consider the work they do to be central to their existence.

In his meta-analysis and review of organizational research, Brown (1996) found that employees who rate high on job involvement are inclined to demonstrate more job effort, are more satisfied with their work, and will be more committed to their organizations and less inclined to quit their jobs than their low job-involvement counterparts. Because of job involvement's positive relationship with motivational processes and, specifically, job-related effort, we predict that highly job-involved employees will be internally motivated to perform TASW or to extend their work time from home with the technological tools provided by their employer. By contrast, low job-involvement employees may not experience the same psychological drive to achieve on the job and, thus, should be less likely to take full advantage of such technological tools to extend their workday.

Conscientiousness. Conscientiousness is one of the Big Five personality dimensions that encompass lower-level traits like being determined, dependable, self-disciplined, achievement-striving, and persevering in one's work (Barrick \& Mount, 1991). It is this desire by a highly conscientious worker to be directed by good work intentions and to engage actively in his/her work that leads the employee to place work-related issues before self.

Barrick, Mount, and Strauss (1993) determined that the salespeople studied who measured high on conscientiousness were more likely to engage independently in goalsetting behaviors and to work diligently toward achieving those goals. Barrick, Piotrowski, and Stewart (2002) also found evidence linking the conscientiousness of subjects and their tendency toward achievement-striving as a means of competing for status amongst their peers and, in so doing, expending greater effort toward a performance goal.

For these reasons, highly conscientious workers are expected to spend greater amounts of personal time after hours at home and on weekends engaged in work-related activities and to use modern technology to facilitate this form of remote work. When work-related objectives at the office are frustrated by day-today distractions, persons measuring high in conscientiousness are expected to use TASW as a means of catching up on their work.

Career Commitment. Career commitment is a dedication to one's "craft, occupation or profession apart from any specific work environment over an extended period of time" (Morrow, 1983, p. 490). Workers can be committed to their careers or jobs despite not being committed to their organizations (Mowday, Porter, \& Steers, 1982). When workers have skills that readily transfer to career positions in a variety of organizations, it is likely that these employees may be highly committed to their careers despite possessing a low commitment toward their organization (Darden, Howell, \& Hampton, 1989). According to Salancik (1977), as cited in Darden et al. (1989), a worker who is committed to his or her career adopts a set of favorable attitudes toward the career that conforms to that commitment. As a result, a worker with high career commitment tends to view his/her job more positively than a worker with low career commitment.

Highly career-committed workers have been found to be more persistent toward attaining their internalized career goals despite the presence of obstacles in their career path (Aryee \& Tan, 1992; Colarelli \& Bishop, 1990). In a study of recent MBA graduates with jobs, Cheng and Ho (2001) found employees who rated themselves high in terms of career commitment were more likely to expend more effort in their jobs, such as seeking out and engaging in training programs.

Thus, it is expected that highly careercommitted employees will more likely view TASW as a means to an end toward improving their career prospects and enhancing personal performance through the additional time and efforts directed toward one's job responsibilities. Not only are these workers expected to be motivated to put forth greater effort, but it is also anticipated that they will work smarter and consider the use of technological tools as a natural extension of their work to achieve their career goals.

\section{... highly conscientious workers are expected to spend greater amounts of personal time after hours at home and on weekends engaged in work-related activities and to use modern technology to facilitate this form of remote work. When work-related objectives at the office are frustrated by day-to-day distractions, persons measuring high in con- scientiousness are expected to use TASW as a means of catching up on their work.}


... perceived usefulness serves to identify workers' preacceptance attitude toward a new technology that is likely formed through secondhand information (supervisors, coworkers, and friends), whereas postacceptance satisfaction rests with a worker's personal experience with the adopted technology.
Proposition 2: Personal innovativeness will be positively related to TASW.

Proposition 3: Job involvement will be positively related to TASW.

Proposition 4: Conscientiousness will be positively related to TASW.

Proposition 5: Career commitment will be positively related to TASW.

\section{Contingency Effect of Perceived Usefulness of Technology and Satisfaction with Adopted Technology}

The strength of the first proposed moderator construct of perceived usefulness of technology characterizes an employee's willingness to adopt the use of provided technologies and is drawn from the technology acceptance model (TAM) developed by Davis (1989) and Davis, Bagozzi, and Warshaw (1989). TAM is a technology-specific theory focused on explaining an employee's adoption of technology use predicated on two decisions. The first one is the perceived usefulness or the user's "subjective probability that using a specific application system will increase his or her job performance" (Davis et al., 1989, p. 985). The second is the perceived ease with which the technology can be used or "the degree to which the . . . user expects the target system to be free of effort" (p. 985). Empirical studies of TAM reveal that perceived usefulness has the strongest effect on whether or not a test subject will adopt the use of e-mail, with the effect of perceived ease of use being indirect and mediated through perceived usefulness (Davis, 1989; Karahanna \& Straub, 1999).

However, Bhattacherjee (2001) questions the ability of prior studies of perceived usefulness (e.g., Davis et al., 1989; Karahanna, Straub, \& Chervany, 1999) to offer an explanation describing why some users discontinue using technology after they have initially adopted the technology. Drawing from marketing's expectation-confirmation theory (ECT), developed by Oliver (1980), Bhattacherjee contends that user satisfaction or positive feelings about the prior use of adopted technology offers a second and even stronger predictor for its continued use than perceived usefulness. Support to this effect was found in a recent study revealing that a technology user's intention to continue to use a recently adopted technology was predicated on both the user's satisfaction with this technology and the perceived usefulness of continued use of the adopted technology (Bhattacherjee, 2001). The study illustrated that a worker's intention to continue to use a recently adopted technology was predicted directly by both satisfaction with the adopted technology and perceived usefulness of the adopted technology, explaining 32\% and 9\% of the variance, respectively.

In light of the strength of earlier research on perceived usefulness pioneered by Davis et al. (1989) and others, as well as the recently revealed importance of satisfaction with adopted technology offered by Bhattacherjee (2001), we have included both constructs as proposed moderators. This rationale is grounded in Bhattacherjee's suggestion that perceived usefulness serves to identify workers' pre-acceptance attitude toward a new technology that is likely formed through secondhand information (supervisors, coworkers, and friends), whereas postacceptance satisfaction rests with a worker's personal experience with the adopted technology.

Thus, Figure 1 suggests the strength of the relationship between an organization's climate to perform TASW, personal innovativeness to perform IT, job involvement, conscientiousness, career commitment, and the use of technological tools to perform supplemental work will each be influenced by (1) the employee's expectation that the use of technological tools will be beneficial and useful and (2) the degree to which the employee is satisfied with the adopted technological tools.

Proposition 6: Perceived usefulness of technology will moderate the relationship between climate and TASW. Specifically, the relationship between climate and TASW will be stronger and more positive 
when perceived usefulness of technology is high than when it is low.

Proposition 7: Perceived usefulness will moderate the relationship between the individual differences (namely, personal innovativeness to perform IT, job involvement, conscientiousness, and career commitment) and TASW. Specifically, the relationship between the individual differences and TASW will be stronger and more positive when perceived usefulness of technology is high than when it is low.

Proposition 8: Satisfaction with adopted technology will moderate the relationship between climate and TASW. Specifically, the relationship between climate and TASW will be stronger and more positive when satisfaction with adopted technology is high than when it is low.

Proposition 9: Satisfaction with adopted technology will moderate the relationship between the individual differences (namely, personal innovativeness to perform IT, job involvement, conscientiousness, and career commitment) and TASW. Specifically, the relationship between the individual differences and TASW will be stronger and more positive when satisfaction with adopted technology is high than when it is low.

\section{TASW, PERFORMANCE, CAREER SUCCESS, AND WORK-TO-FAMILY CONFLICT}

Employees who engage in TASW are expected to be better performers, achieve higher levels of career success, and potentially experience greater work-to-family conflict than their peers who do not engage in TASW. However, the extent to which the relationship with performance is realized may likely be influenced by the media richness of technology selected to perform TASW and the complexity of the tasks attended to by TASW. Furthermore, it is suggested that the time- and boundary-management skills of the employee will reduce the positive relationship predicted between TASW and work- to-family conflict. In the following sections, we analyze in greater detail the relationship between TASW and these outcomes.

\section{TASW and Performance}

Performance in this article refers to the behaviors or actions of workers that contribute to the goals of their organization (Campbell, 1990). Broadly defined as such, performance would be expected to include the technical skills and job-specific knowledge that the workers demonstrate in their work roles, the quality of their interactions with coworkers, supervisors, and customers, and a willingness to exert effort. In this section, we will draw on the job characteristics model (JCM) and recent research on telecommuters to bridge increased levels of TASW with superior job performance.

Caldwell and Koch's (1999) qualitative study of ten firms engaged in mobile computing strategies illustrates that $60 \%$ of the firms studied identified improved flexibility in communicating with customers, enhanced customer satisfaction, and reduced cycle times in decision making as overarching goals they expected to achieve by adopting this distributed work form. The authors attribute the performance improvements to the workers' higher internal work motivation resulting from the skill variety, task identity, task significance, autonomy, and feedback in the design of jobs involving mobile computing (Fried \& Ferris, 1987; Hackman \& Oldham, 1976).

According to Caldwell and Koch (1999), the remote computing jobs they studied provided greater skill variety and task identity due to the broadened array of job functions associated with work augmented by computer-mediated technology. In many instances, the use of laptop computers networked with other sources of data facilitated the ability of these workers to perform a complete job from start to finish. This removed the need for gatekeepers and other information brokers from the work process that had frustrated task completion in the past. The workers interpreted their new work role as possessing greater significance due to their unfettered access to larger amounts of ..performance would be expected to include the technical skills and job-specific knowledge that the workers demonstrate in their work roles, the quality of their interactions with coworkers, supervisors, and customers, and a willingness to exert effort. 
The visibility of TASW performed by an employee and observed by his or her supervisor presents a potential paradox with respect to a supervisor's ratings of job performance and warrants brief discussion. critical information relevant to sound decision making as well as the closer customer relationship this technology produced by means of direct e-mail contact. The positive impact on perceived autonomy was driven in part by the independence with which they could decide when best to employ the use of available technological tools. And, finally, feedback originating from internal and external customers with respect to their satisfaction was more immediate and direct than that which comparatively could be expected from a supervisor.

Further support for a TASW and jobperformance relationship comes from studies of telecommuters, who represent another group of remote workers relying upon the use of advanced information technology to perform their jobs. Telecommuters working remotely with the aid of technology have demonstrated performance improvements of $2 \%$ to $40 \%$ (Atkinson, 1985 , as cited by Chapman, Sheehy, Heywood, Dooley, \& Collins, 1995). Explanations for this increased performance range from the increased motivation engendered from workers' perceptions of greater flexibility with remote work, lack of disruptions at home common to office environments, and more work autonomy to the suggestion that these workers are typically self-selected and thus more motivated to perform this kind of work in the first place (Allen \& Renn, 2002; Chapman et al., 1995; O’Mahony \& Barley, 1999).

The visibility of TASW performed by an employee and observed by his or her supervisor presents a potential paradox with respect to a supervisor's ratings of job performance and warrants brief discussion. On the one hand, performance of TASW may serve as a surrogate for additional "face time" with a supervisor that positively reinforces the supervisor's subjective evaluation of the employee's performance, such as when the employee CCs or BCCs the supervisor on an e-mail related to contacting a customer and satisfying an emergency request from home after hours or on weekends. Conversely, TASW that remains invisible, such as handling a similar matter by cell phone, might pass unnoticed by the supervisor and, thus, is not likely to influence supervisory job-performance ratings.

\section{TASW and Career Success}

Career success has been defined traditionally in objective terms by the increases in income and one's progression up the hierarchical ladder with promotion into jobs with increasing responsibility and authority (O'Reilly \& Chatman, 1994). As the structures of careers have changed in response to flattened hierarchies, fewer promotion opportunities, and boundaryless careers, scholars have called for the study of subjective career success by measuring a worker's satisfaction with his or her career achievements (Friedman \& Greenhaus, 2000; Gattiker \& Larwood, 1988; Sullivan, 1999).

Objective Career Success. Signaling theory offers an explanation for the results of employee selection or promotion processes within an organization influenced by observable characteristics of the employee that he/she controls and can manipulate (Spence, 1973). Firms, as an example, often are required to make promotion decisions with imperfect information (Rosenbaum, 1989). Barney and Lawrence (1989) suggested that, in such instances, employers differentiated promotable from unpromotable employees by the signals elicited by those employees that were clearly observable. These signals amounted to employee attributes that mirrored important organizational norms or traditions such as level of education attained. However, research going back more than 50 years suggests that career advancement seems less affected by an employee's formal education or seniority with the organization than by the strategic behaviors of job incumbents (Dalton, 1951; Jennings, 1971). We suggest that workers possess the ability to include the use of signals as an element of their overall career strategy by way of their strategic behaviors.

A career strategy can be interpreted as a group of signals adopted and manipulated by jobholders. Gould and Penley (1984) define career strategies as "job behaviors utilized to decrease the time required for and the uncertainty surrounding the attainment of im- 
portant career objectives" (p. 244). An example of a career strategy proposed in this analysis is conveying an image of promotability through extended work involvement. Working more than 40 hours a week and commonly bringing home work at night or on weekends during one's earlier career signals a preoccupation with work beyond the boundary of the traditional work environment and conveys an image of success and promotability (Barney \& Lawrence, 1989; Greenhaus \& Callanan, 1994). In fact, the number of hours worked was the most significant predictor for a number of promotions received and total compensation earned by all respondents in a longitudinal study of MBAs by Whitely, Dougherty, and Dreher (1991). We expect that the performance of TASW will represent a career strategy signaling superiors that the employee is concerned with their career; in response, their superiors will evaluate them as being more promotable than employees who do not engage in TASW, and, in turn, these employees will receive more promotions and other objective indicators of career success such as greater responsibility, authority, and remuneration.

Subjective Career Success. Gattiker and Larwood (1988) encourage researchers to investigate career success from both the objective perspective visible to others and the subjective perspective known only to the subject. Their rationale rests on the premise that society may not judge career success in the same manner as the actual career participant might. Although research suggests the attainment of promotions and pay raises is positively related to subjective career success and job satisfaction, some people may have a more difficult time obtaining a measure of objective career success (Judge, Cable, Boudreau, \& Bretz, 1995). As an example, people employed in flattened organizations, older workers with limited promotional opportunities, women constrained by glass ceilings, or technicians who value careers of achievement rather than careers of advancement may be judged as having obtained lower objective career success. Simultaneously, these same workers may possess stronger feelings of career satisfaction and subjective career success (Sturges, 1999; Zabusky \& Barley, 1996). That said, although employees may have failed to achieve objective career success, these same employees, by way of their performance of TASW, will experience personal rewards and personal satisfaction that will lead to a feeling of career satisfaction.

\section{TASW and Work-to-Family Conflict}

Greenhaus and Beutell (1985) describe work-family conflict as the tension resulting from the incompatible pressures of work and family that constrain a person's ability to satisfactorily fulfill one role at the expense of the other. Work routines, one's commitment to work, presence of a spouse, children, or other dependents, and the likelihood that the spouse is additionally employed serve to contribute to the imposition of pressures capable of producing work-to-family conflict. Since work-family conflict is a bidirectional construct, we focus on work-to-family conflict, which more clearly describes the direction of the role conflict (Gutek, Searle, \& Klepa, 1991; Kossek \& Ozeki, 1998). Research in this area has also determined that despite a consistent negative relationship existing between both work-to-family and family-towork conflict on such outcomes as job-life satisfaction, work interference with one's family was inclined to exert a much greater negative effect than family-to-work conflict (Kossek \& Ozeki, 1998).

When engaged in TASW, the worker who may also be a member of a family is not readily available, either psychologically or physically, to pursue those responsibilities deemed to be of importance by the nonwork or family role. When work represents the most important values embraced by the worker, conflict may ignite within the family. This conflict serves to motivate the worker to disengage from the preferred work activity so he/she is free to redirect efforts to a family-oriented activity, which holds lower value, and, thus, increases dissatisfaction in that domain (Carlson \& Kacmar, 2000). Spillover theory suggests that this dissatisfaction tends to spill back over into the work
We expect that the performance of TASW will represent a career strategy signaling superiors that the employee is concerned with their career; in response, their superiors will evaluate them as being more promotable than employees who do not engage in TASW, and, in turn, these employees will receive more promotions and other objective indicators of career success such as greater responsibility, authority, and remuneration. 
Media richness theory is an individual-level rational choice theory that suggests managers can improve their performance by balancing the media characteristics of $a$ communication medium with the routineness of a message. domain and, thus, creates an opportunity for the family to interfere with work (Bartolome \& Evans, 1980).

Therefore, we predict that TASW performed by workers represents an impediment to the fulfillment of family and nonwork roles and, in turn, a positive relationship between TASW and experienced work-to-family conflict is expected.

Proposition 10: Employees who engage regularly and visibly in TASW will be judged more positively in their job performance.

Proposition 11: Employees who engage regularly in TASW will attain higher levels of objective career success.

Proposition 12: Employees who engage regularly in TASW will report higher levels of subjective career success.

Proposition 13: Employees who engage regularly in TASW will report more work-tofamily conflict.

\section{Contingency Effect of Media Richness and Time- and Boundary-Management Skills}

Managers communicate with others in order to reduce uncertainty and clarify the ambiguity in their work environment (Daft \& Lengel, 1988). Media richness theory is an individual-level rational choice theory that suggests managers can improve their performance by balancing the media characteristics of a communication medium with the routineness of a message (Daft \& Lengel, 1984). A comprehensive study involving the simultaneous testing of a wide array of theories, including media richness, and their relationship to media choices, attitudes, and use found further and continuing support for this theory (Trevino, Webster, \& Stein, 2000). Trevino et al. found (1) the ambiguity of a message served to guide media choices by managers, (2) managers holding jobs that were highly ambiguous influenced media use, and (3) perceived richness by communicators held the greatest influence on directing media attitudes.
Media richness theory suggests that communication methods will vary in their richness or capacity to transmit information that enables both the transmitter and receiver to accurately communicate and reach understanding with each other. Richer media, like video-conferencing or cell phone use, not only conveys a direct message, but also indirectly augments the central message with verbal and nonverbal information cues and rapid feedback to facilitate understanding. Rich media represents a synchronous communication medium where the message from the sender is received instantly by the recipient without the delays common with voice-mail or e-mail systems, where the recipient may not acknowledge message receipt until they listen to their voice messages or access their e-mail server and check for incoming messages.

A richer medium minimizes opportunities for misunderstanding of message content and meaning. According to Daft and Lengel (1984, 1988), richer media are more desirable media choices for managers when they face nonroutine and ambiguous circumstances where a greater chance for misunderstanding exists. Leaner media, like the use of computer-mediated technology and email, filters out many of the information cues common to richer media alternatives. Not only does e-mail lack the ability to communicate a full spectrum of information cues common to richer media like video-conferencing or cell phones, but it is also asynchronous, since the transmission and receipt of the communication message is decoupled. The use of lean media is best limited to routine tasks that are simpler, more straightforward, and less likely to lead to misunderstanding or surprise.

In particular, we propose that media richness interacts with TASW to influence job performance and career success. A worker who fails to select the proper media for the communication needs of the task in their performance of TASW may experience lower performance evaluations and less career success than workers who do a better job of matching the communication needs of their tasks with TASW. As an example, a worker who is engaging in TASW and relies 
upon the use of a cell phone to communicate a litany of statistical data or to set an appointment date with his or her superior and coworkers is using too rich a medium for a routine task. Tasks such as these are best served by lean media like e-mail. On the other hand, depending upon the use of email to settle a conflict between two subordinates or relying upon this asynchronous communication form to deliver time-sensitive material or establish a deadline are examples of selecting too lean a media for a nonroutine and ambiguous task. Situations such as these would be better served by use of richer media such as a cell phone.

Drawing on leader-member exchange theory (LMX), employees who select the right media for their task while engaging in TASW are more inclined to please their supervisor and, thus, build a high-quality relationship between themselves and their superior. An empirical study by Liden and Maslyn (1998) and a meta-analytic review of LMX by Gerstner and Day (1997) suggest that a highquality LMX is positively related to performance outcomes. Additionally, the career mentoring offered by the supervisor to the subordinate with a high-quality LMX serves to bolster the subordinate's opportunities for achieving objective career success, as well as more subjective satisfaction outcomes (Gerstner \& Day, 1997; Scandura \& Schriesheim, 1994). Therefore, we expect that both the job performance and career success of employees engaged in TASW will be influenced by their ability to select the technological tools possessing the correct media richness for the task at hand.

Proposition 14: Media richness will moderate the TASW and job-performance relationship. Specifically, the relationship between TASW and job performance will be stronger and more positive when the technology selected to perform TASW possesses a media richness that best matches the routineness of the task to be performed by TASW.

Proposition 15: Media richness will moderate the TASW and career success relationship. Specifically, the relationship between
TASW and career success will be stronger and more positive when the technology selected to perform TASW possesses a media richness that best matches the routineness of the task to be performed by TASW.

The proposed moderator of time management has been identified as a multidimensional individual-level construct with multiple factors relating to achievement strivings: (1) the setting of goals/priorities, (2) scheduling and planning of activities, and (3) a preference for organization as timemanagement dimensions (Macan, 1994; Macan, Shahani, Dipboye, \& Phillips, 1990). Individuals who excel at time management are inclined to differ in their experience of time by overestimating the passage of time, scheduling numerous objectives to be achieved within a specific period of time, engaging in self-set deadlines, and consistently monitoring their performance of time expended to time remaining to complete a task (Rastegary \& Landy, 1993; Waller, Conte, Gibson, \& Carpenter, 2001). These individuals seek to accomplish a greater number of objectives than available time would ordinarily permit and are driven to improve personal efficiency. Employees who excel in time management adopt tactics or work strategies that enable them to better develop and improve personal efficiency (Rastegary \& Landy, 1993).

The effective use of time management is expected to lessen TASW's positive influence on work-to-family conflict. Time pressure and resulting time-based conflict contributes to work-to-family conflict. Time pressures and resulting time-based conflict can result when work-role performance interferes with a worker's ability to fulfill family-role expectations (Greenhaus \& Beutell, 1985). Employees who are skilled time managers are expected to better balance the demands of work and family by their careful application of time in satisfying the demands imposed by each domain. The effective time manager will be more organized and more likely to carefully prioritize and schedule the performance of both family responsibilities and any work-related tasks, such as TASW, when at home. The performance of TASW by effec-

\author{
Employees who \\ are skilled time \\ managers are \\ expected to \\ better balance \\ the demands \\ of work and \\ family by their \\ careful \\ application \\ of time in \\ satisfying the \\ demands \\ imposed by \\ each domain.
}


A worker who manages clearly defined and highly segmented boundaries between work and family may still engage in TASW, but will likely perform TASW at times when family members are asleep or otherwise not present and, thus, produce less opportunity for work-tofamily conflict. tive time managers is less likely to produce work-to-family conflict because these workers are more likely to possess the capacity to satisfactorily manage family responsibilities while efficiently performing TASW in a manner that minimizes the disruption of domestic routines.

Proposition 16: Time management will moderate the relationship between TASW and work-to-family conflict. As the time management skills of workers increases, the expected positive relationship between TASW and work-to-family conflict will be weaker.

Some employees manage the boundaries separating work from family better than others and, thus, experience less conflict between these two domains. Nippert-Eng (1996) describes boundary management as "the strategies, principles, and practices we use to create, maintain, and modify cultural categories" (p. 7). Her research reveals that the boundaries people erect around these cultural categories vary on a continuum ranging from the highly segmented, which create mutually exclusive worlds permitting little or no overlap between domains, to highly integrative boundaries that offer little separation that distinguishes one domain (e.g., work) from another domain (e.g., home). According to Ashforth et al. (2000), workers who erect very inflexible, impermeable, and highly differentiated boundaries around work and home establish role behaviors within these domains that are time- and place-specific, contrast markedly from one domain to the other, and discourage crossrole interruptions. On the other hand, the authors suggest that less structured and permeable boundaries between work and home promote integrative role behaviors capable of producing more cross-role interruptions.

As an example, workers with integrative or flexible and permeable boundaries between work and home tend to allow their work roles to transcend or overlap into the home domain. They are less likely to discourage work-related phone calls, may use common areas in the home to perform workrelated tasks, and will be more likely to inte- grate work tasks such as TASW with family activities. According to Friedman and Greenhaus (2000), research has suggested that the presence of integrative boundaries constitutes the main ingredient for work-to-family conflict and "we must learn how to leave work behind and enjoy family life when we're at home-in other words, to separate or segment our work and family roles at certain times" (p. 138).

Workers who erect highly segmented boundaries around work and home tend to discourage work-related activities from encroaching into the home and vice versa. They are more inclined to carefully schedule their work and domestic tasks to avoid interference with one another and carefully identify times in which people from one domain can call or talk to them when they are in another domain. A worker who manages clearly defined and highly segmented boundaries between work and family may still engage in TASW, but will likely perform TASW at times when family members are asleep or otherwise not present and, thus, produce less opportunity for work-to-family conflict.

Proposition 17: Boundary management skills will moderate the relationship between TASW and work-to-family conflict. As more segmented boundaries are created by employees, the expected positive relationship between the performance of TASW and work-to-family conflict will be weaker.

\section{IMPLICATIONS AND CONCLUSION}

This framework extends Venkatesh and Vitalari's (1992) work by explicating a new form of supplemental work and by identifying predictors, consequences, and moderators of technology-assisted supplemental work (TASW). The growing use of advanced information technologies in the performance of work after "normal" working hours, and growing attention in the popular press in the face of limited scientific research on TASW warrants theoretical and empirical attention to this construct (Boyd, 1997; Galinsky et al., 2001; King, 1998). Our analysis clarifies the roles of selected organizational and individual characteristics in the performance of 
TASW and how the perceived usefulness of and satisfaction with adopted technologies affect the performance of TASW. In addition, it explains why performing TASW does not always enhance job performance or career success because of mismatching technological tools with a task. The framework also shows that time- and boundary-management skills determine the impact of TASW on work-to-family conflict.

Researchers argue that social forces and control factors within the work environment affect employee use of technology (Barclay et al., 1995; Jones et al., 2002; Mathieson, 1991). Our analysis incorporates climate for TASW as a new and parsimonious construct that encompasses many of the social forces and control factors that partly determine whether employees will use computers, cell phones, beepers, BlackBerries ${ }^{\circledR}$ (wireless handheld devices for sending and receiving e-mail messages), PDAs (personal digital assistants), and so forth to perform supplemental work. Goals, task-related methods, resources, behavioral norms, and supervisor support that converge on the importance of performing TASW (i.e., strong climates) cue employees to the importance of performing TASW and motivate them to maximize their use of available technological tools to perform supplemental work (Kopelman et al., 1990). By contrast, weak climates fail to motivate employees in this way by sending scattered signals to employees about the organization's position on performing TASW (Schneider, 1990). Yet, even the positive effects of a strong climate for TASW have limitations. According to the technology acceptance model, a strong climate will promote TASW when employees believe that the technological tools provided by the organization increase job performance and employees are satisfied with the technology (Bhattacherjee, 2001; Davis, 1989; Davis et al., 1989). This highlights the importance of human resource managers not only aligning goals, job methods, resources, and supervisor practices with TASW but also pointing out to employees the value of using available technological tools and ensuring that they are satisfied with the particular tools provided by the organization.
Individual-level characteristics like job involvement, conscientiousness, career commitment, and, in particular, personal innovativeness in technology predispose employees to perform TASW. Personal innovation in information technology (PITT), for example, is a recently identified and relatively untested individual-level characteristic that promises a greater understanding of why some people will more quickly adopt new technologies than others. Prior studies have viewed PITT as a moderator between management's espoused use of technology and user intentions (Leonard-Barton \& Deschamps, 1988) or as having a positive relationship with computer self-efficacy and a negative relationship with computer anxiety (Thatcher \& Perrewe, 2002). Only recently have studies used PITT as a predictor of technology's infusion into the work domain with promising results (Jones et al., 2002). Our analysis points toward the potential utility of practitioners selecting employees who rank high on this individual difference for jobs requiring TASW and invites researchers to study this construct as well as the others' influence on potential adopters of technology (Agarwal \& Prasad, 1998).

The framework illustrates that TASW's associations with job performance, career success, and work-to-family conflict are complex. Media richness captures the influence that the appropriate "fit" between the technology selected and task routineness has on the relationship between TASW and job performance and career success. The "fit" argument encourages greater exploration of the evolving richness of technologies that, in the past, have been deemed relatively lean. E-mail, as an example, traditionally has been ranked low in richness and yet has been deemed to be a medium of choice by a growing number of managers (Kock, 2001; Markus, 1994). Although Markus (1994) and Kock $(2001,2002)$ rely upon social influence, compensatory adaptation, and media naturalness theory to help explain email's growing popularity and successful use in facilitating equivocal tasks, media richness theory alternatively suggests that email's growing success lies in its ability to add cues with the use of emoticons within a

\author{
Media richness \\ captures the \\ influence that \\ the appropriate \\ "fit" between \\ the technology \\ selected and \\ task routineness \\ has on the \\ relationship \\ between TASW \\ and job \\ performance \\ and career \\ success.
}


message's text or its use with BlackBerries ${ }^{\circledR}$, where e-mail text messaging can be monitored and used synchronously, much like communication via cell phone.

Technology-assisted supplemental work may pierce the boundaries between the family and work domains and, thus, contribute to work-to-family conflict. Ashforth et al. (2000) warn that the role boundaries surrounding work and home are not always balanced and that the popular use of technological tools like pagers, cell phones, and e-mail constitutes a real threat of work encroaching into the home domain. However, we counter this dire prediction by proposing that time and boundary management has the power to lessen the intrusion of TASW on the family domain. Researchers are just beginning to unpack the time- and boundary-management constructs and relate them to work outcomes (Macan, 1994; Rastegary \& Landy, 1993;
Waller et al., 2001). However, our analysis indicates that workers who schedule and exploit their time wisely in their responsibilities at home and work and who set reasonably separate boundaries between work and family should be far less likely to experience work-to-family conflict due to performing TASW (Ashforth et al., 2000; Nippert-Eng, 1996). We believe these predictions of time and boundary management offer valuable insights to human resource managers and researchers on how workers can meet the increased performance demands of their jobs and achieve career success without sacrificing their family commitments.

The authors wish to acknowledge the insights and helpful contributions offered by David Allen, Jim Van Scotter, and Ronald Wilkes, as well as those offered by the anonymous reviewers.

Grant H. Fenner is an assistant professor of organizational behavior at Arkansas State University and a PhD candidate at the University of Memphis. His dissertation research is on the extra-work behaviors exhibited by managerial and professional workers facilitated by the use of digitized technology. He has also co-written a leading section of a book chapter describing the voluntary turnover behaviors of technical professionals who opt out of traditional employment in favor of contingent work. Before beginning his doctoral studies, Grant enjoyed a successful business career spanning 23 years in the environmental services industry.

Robert W. RENN earned his doctorate in business administration in 1989 from Georgia State University. His dissertation research focused on job redesign, and his current research interests are self-leadership failure, organizational learning, and managing remote workers. Dr. Renn's research has been published in the Journal of Management, Human Relations, Educational and Psychological Measurement, Research in Personnel and Human Resource Management, Human Resource Management Review, Compensation and Benefits Review, and Group and Organization Management, among others. Prior to earning his doctorate, Dr. Renn worked in architecture for six years and served in the U.S. Marine Airwing from 1974-1978.

\section{REFERENCES}

Agarwal, R., \& Prasad, J. (1998). A conceptual and operational definition of personal innovativeness in the domain of information technology. Information Systems Research, 9, 204-215.

Allen, D., \& Renn, R. (2002). Telecommuting: Un- derstanding and managing remote workers. In G. Ferris, R. Buckley, \& D. Fedor (Eds.), Human resources management (pp. 145-155). Upper Saddle River, NJ: Prentice Hall.

Allen, D., Renn, R., \& Griffeth, R. (2003). The impact of telecommuting design on social systems, self-regulation, and role boundaries. In J. 
Martocchio \& G. Ferris (Eds.), Research in personnel and human resources management (Vol. 22, pp. 125-163). Oxford, UK: Elsevier.

Aryee, S., \& Tan, K. (1992). Antecedents and outcomes of career commitment. Journal of Vocational Behavior, 40, 288-305.

Ashforth, B., Kreiner, G., \& Fugate, M. (2000). All in a day's work: Boundaries and micro role transitions. Academy of Management Review, 25, 472-491.

Atkinson, W. (1985). Homework. Personnel Journal, 64, 104-109.

Barclay, D., Higgins, C., \& Thompson, R. (1995). The partial least squares approach to causal modeling. Technology Studies, 2, 285-309.

Barney, J., \& Lawrence, B. (1989). Pin stripes, power ties, and personal relationships: The economics of career strategy. In M. Arthur, D. Hall, \& B. Lawrence (Eds.), Handbook of career theory (pp. 417-436). New York: Cambridge University Press.

Barrick, M., \& Mount, M. (1991). The Big Five personality dimensions and job performance: A meta-analysis. Personnel Psychology, 44, 1-26.

Barrick, M., Mount, M., \& Strauss, J. (1993). Conscientiousness and performance of sales representatives: Test of the mediating effects of goal setting. Journal of Applied Psychology, 78, 715-722.

Barrick, M., Piotrowski, M., \& Stewart, G. (2002). Personality and job performance: Test of the mediating effects of motivation among sales representatives. Journal of Applied Psychology, $87,43-51$.

Bartolome, F., \& Evans, P. (1980). Must success cost so much? Harvard Business Review, 58, 137-148.

Bhattacherjee, A. (2001). Understanding information systems continuance: An expectation-confirmation model. MIS Quarterly, 25, 251-269.

Boyd, F. (1997). The puppet on a string. Management Services, 41, 38-39.

Brown, S. (1996). A meta-analysis and review of organizational research on job involvement. Psychological Bulletin, 120, 235-255.

Caldwell, D., \& Koch, J. (1999). Mobile computing and its impact on the changing nature of work and organizations. Technical report, Santa Clara University, Center for Science, Technology \& Society, Santa Clara, CA.

Campbell, J. (1990). Modeling the performance prediction problem in industrial and organizational psychology. In M. Dunnette \& L. Hough (Eds.), Handbook of industrial and organizational psychology (2nd ed., pp. 688-732). Palo Alto, CA: Consulting Psychologists Press.

Carey, R. (1996, June 14). A balancing act. Sales and Marketing Management. pp. 14-18.

Carlson, D., \& Kacmar, M. (2000). Work-family conflict in the organization: Do life role values make a difference? Journal of Management, 26, 1031-1054.

Chapman, A., Sheehy, N., Heywood, S., Dooley, B., \& Collins, S. (1995). The organizational implications of teleworking. In C. Cooper \& I. Robertson (Eds.), International review of industrial and organizational psychology (pp. 229-248). New York: Wiley.

Cheng, E., \& Ho, D. (2001). The influence of job and career attitudes on learning motivation and transfer. Career Development International, 6, 20-28.

Colarelli, S., \& Bishop, R. (1990). Career commitment: Functions, correlates and management. Group and Organization Studies, 15, 158-176.

Daft, R., \& Lengel, R. (1984). Information richness: A new approach to managerial behavior and organizational design. In B. Staw \& L. Cummings (Eds.), Research in organizational behavior (pp. 191-233). Greenwich, CT: JAI Press.

Daft, R., \& Lengel, R. (1988). Selection of communication media as an executive skill. Academy of Management Executive, 2, 225-232.

Dalton, M. (1951). Informal factors in career advancement. American Journal of Sociology, 56, 407-415.

Darden, W., Howell, R., \& Hampton, R. (1989). Career versus organizational commitment: Antecedents and consequences of retail salespeoples' commitment. Journal of Retailing, 65, 80-104.

Davis, F. (1989). Perceived usefulness, perceived ease of use and user acceptance of information technology. MIS Quarterly, 13, 319-340.

Davis, F., Bagozzi, R., \& Warshaw, P. (1989). User acceptance of computer technology: A comparison of two theoretical models. Management Science, 35, 982-1003.

Do laptops and LANS translate into longer working hours? (1998, January). CPA Journal, p. 9.

Fried, Y., \& Ferris, G. (1987). The validity of the job characteristics model: A review and meta-analysis. Personnel Psychology, 40, 287-322.

Friedman, S., \& Greenhaus, J. (2000). Work and 
Family_Allies or Enemies? New York: Oxford Press.

Galinsky, E. (1992). Work and family 1992: Status report and outlook. New York: Families and Work Institute.

Galinsky, E., Kim, S., \& Bond, J. (2001, May 16). Feeling overworked: When work becomes too much. Paper presented at The Conference Board/Families and Work Institute's Work-Life 2001 Conference, New York, NY.

Gattiker, U., \& Larwood, L. (1988). Predictors for managers' career mobility, success, and satisfaction. Human Relations, 41, 569-591.

Gerstner, C., \& Day, D. (1997). Meta-analytic review of leader-member exchange theory: Correlates and construct issues. Journal of Applied Psychology, 82, 827-844.

Gordon, G. (2001). Turn it off. New York: Three Rivers Press.

Gould, S., \& Penley, L. (1984). Career strategies and salary progression: A study of their relationships in a municipal bureaucracy. Organizational Behavior and Human Performance, 34, 244-265.

Greenhaus, J., \& Beutell, N. (1985). Sources of conflict between work and family roles. The Academy of Management Review, 10, 76-88.

Greenhaus, J., \& Callanan, G. (1994). Career management. Fort Worth, TX: The Dryden Press.

Gutek, B., Searle, S., \& Klepa, L. (1991). Rational versus gender role explanations for work-family conflict. Journal of Applied Psychology, 76, 560-568.

Hackman, J., \& Oldham, G. (1976). Motivation through the design of work: A test of a theory. Organizational Behavior and Human Performance, 16, 250-279.

Higgins, C., Duxbury, L., \& Irving, R. (1992). Workfamily conflict in the dual career family. Organizational Behavior and Human Decision Processes, 51, 51-75.

Huber, G. (1983). Cognitive style as a basis for MIS and DSS designs: Much to do about nothing? Management Science, 29, 567-579.

Hutchison, S., Sowa, D., Eisenberger, R., \& Huntington, R. (1986). Perceived organizational support. Journal of Applied Psychology, 71, 500-508.

Igbaria, M., Parasuraman, S., \& Badawy, M. (1994). Work experiences, job involvement, and quality of work life among information systems personnel. MIS Quarterly, 18, 175.

Jennings, E. (1971). Routes to the executive suite. New York: Macmillan.
Jones, E., Sundaram, S., \& Chin, W. (2002). Factors leading to sales force automation use: A longitudinal analysis. Journal of Personal Selling, 22, 145-156.

Judge, T., Cable, D., Boudreau, J., \& Bretz, R. (1995). An empirical investigation of the predictors of executive career success. Personnel Psychology, 48, 485-520.

Kanungo, R. (1982). Measurement of job and work involvement. Journal of Applied Psychology, 67, 341-349.

Karahanna, E., \& Straub, D. (1999). The psychological origins of perceived usefulness and ease-ofuse. Information Management, 35, 237-250.

Karahanna, E., Straub, D., \& Chervany, N. (1999). Information technology adoption across time: A cross sectional comparison of pre-adoption and post adoption beliefs. MIS Quarterly, 23, 183-213.

King, J. (1998). Long hours, cold dinners and vacation interrupts. Computerworld, 32, 1.

Kock, N. (2001). Compensatory adaptation to a lean medium: An action research investigation of electronic communication in process improvement groups. IEEE Transactions on Professional Communication, 44, 267-284.

Kock, N. (2002, December 15-18). Evolution and media naturalness: A look at e-communication through a Darwinian theoretical lens. In L. Applegate, R. Galliers, \& J. L. DeGross (Eds.), Proceedings of the 23rd International Conference on Information Systems, Barcelona, Spain (pp. 373-382). Atlanta, GA: The Association for Information Systems.

Kopelman, R., Brief, A., \& Guzzo, R. (1990). The role of climate and culture in productivity. In B. Schneider (Ed.), Organizational climate and culture (pp. 282-318). San Francisco: Jossey-Bass.

Kossek, E., \& Ozeki, C. (1998). Work-family conflict, policies, and the job-life satisfaction relationship: A review and directions for organizational behavior-human resources research. Journal of Applied Psychology, 83, 139-149.

Kraut, R. (1989). Predicting the use of technology: The case of telework. In R. E. Kraut (Ed.), Technology and the transformation of whitecollar work (pp. 113-133). Hillsdale, NJ: Erlbaum Associates Publishers.

Leonard-Barton, D., \& Deschamps, I. (1988). Managerial influence in the implementation of new technology. Management Science, 34, 1252-1265. 
Liden, R., \& Maslyn, J. (1998). Multidimensionality of leader-member exchange: An empirical assessment through scales development. Journal of Management, 24, 43-72.

Locke, E., Shaw, K., Saari, L., \& Latham, G. (1981). Goal setting and task performance. Psychological Bulletin, 90, 125-152.

Louis, M. (1990). Acculturation in the workplace: Newcomers as lay ethnographers. In B. Schneider (Ed.), Organizational climate and culture (pp. 85-129). San Francisco: Jossey-Bass.

Macan, T. (1994). Time management: Test of a process model. Journal of Applied Psychology, 79, 381-391.

Macan, T., Shahani, C., Dipboye, R., \& Phillips, A. (1990). College students' time management: Correlations with academic performance and stress. Journal of Educational Psychology, 82, 760-768.

Markus, M. (1994). Electronic mail as the medium of managerial choice. Organizational Science, 5, 502-527.

Marsan, C. (2001). Wired workforce plans stress corporate nets. Network World, 18, 1 and 86.

Mathieson, K. (1991). Predicting user intentions: Comparing technology acceptance model with theory of planned behavior. Information Systems Research, 2, 173-191.

McAfee, R., \& Champagne, P. (1993). Performance management: A strategy for improving performance and productivity. Journal of Managerial Psychology, 8, 24.

Morrow, P. (1983). Concept redundancy in organizational research: The case of work. Academy of Management Review, 8, 486-499.

Mortimer, J., \& Simmons, R. (1978). Adult socialization. Annual Review of Sociology, 4, 421-454.

Mowday, R., Porter, L., \& Steers, R. (1982). Employee organizational linkages. New York: Academic Press.

Nippert-Eng, C. (1996). Home and work: Negotiating boundaries through everyday life. Chicago: The University of Chicago Press.

Oliver, R. (1980). A cognitive model for the antecedents and consequences of satisfaction. Journal of Marketing Research, 17, 460-469.

O’Mahony, S., \& Barley, S. (1999). Do digital telecommunications affect work and organization? In R.I. Sutton (Ed.), Research in organizational behavior (Vol. 21, pp. 125-161). Greenwich, CT: JAI Press.

O'Reilly, C., \& Chatman, J. (1994). Working longer and harder: A longitudinal study of managerial success. Administrative Science Quarterly, 39, 604-627.

Ostroff, C., \& Schmitt, N. (1993). Configurations of organizational effectiveness and efficiency. Academy of Management Journal, 36, 1345-1357.

Rastegary, H., \& Landy, F. (1993). The interactions among time urgency, uncertainty, and time pressure. In O. Svenson \& A. Maule (Eds.), Time pressure and stress in human judgement and decision making (pp. 217-239). New York: Plenum Press.

Rosenbaum, J. (1989). Organization career systems and employee misperceptions. In M. Arthur, D. Hall, \& B. Lawrence (Eds.), Handbook of career theory (pp. 329-353). New York: Cambridge University Press.

Rousseau, D. (1990). Assessing organizational culture: The case for multiple methods. In B. Schneider (Ed.), Organizational climate and culture (pp. 153-192). San Francisco: Jossey-Bass.

Salancik, G. (1977, Summer). Commitment is too easy. Organizational Dynamics, 62-80.

Scandura, T., \& Schriesheim, C. (1994). Leadermember exchange and supervisor career mentoring as complementary constructs in leadership research. Academy of Management Journal, 37, 1588-1602.

Schneider, B. (1990). The climate for service: An application of the climate construct. In B. Schneider (Ed.), Organizational climate and culture (pp. 383-412). San Francisco: Jossey-Bass.

Schneider, B., Gunnarson, S., \& Niles-Jolly, K. (1994). Creating the climate and culture of success. Organizational Dynamics, 23, 17-29.

Schneider, B., \& Rentsch, J. (1988). Managing climates and cultures: A future perspective. In J. Hage (Ed.), Futures of organizations (pp. 181-200). Lexington, MA: Lexington Books.

Schneider, B., White, S., \& Paul, M. (1998). Linking service climate and customer perceptions of service quality: Test of a causal model. Journal of Applied Psychology, 83, 150-163.

Shore, L., \& Tetrick, L. (1991). A construct validity study of the survey of perceived organizational support. Journal of Applied Psychology, 76, 637-643.

Skinner, B. (1969). Contingencies of reinforcement. New York: Appleton-Century-Crofts.

Spence, M. (1973). Job market signaling. Quarterly Journal of Economics, 87, 355-374. 
Staples, D. (2001). A study of remote workers and their differences from non-remote workers. Journal of End User Computing, 12, 3-14.

Stevens, G., \& Szajna, B. (1998). Perceptions and expectations: Why people choose a telecommuting lifestyle. International Journal of Electronic Commerce, 3, 70-85.

Sturges, J. (1999). What it means to succeed: Personal conceptions of career success held by male and female managers at different ages. British Journal of Management, 10, 239-252.

Sullivan, S. (1999). The changing nature of careers: A review and research agenda. Journal of Management, 25, 457-484.

Taylor, P., \& Pierce, J. (1999). Effects of introducing a performance management system on employee's subsequent attitudes and effort. Public Personnel Management, 28, 423-452.

Thatcher J., \& Perrewe, P. (2002). An empirical examination of individual traits as antecedents to computer anxiety and computer self-efficacy. MIS Quarterly, 26, 381-396.

Trevino, L., Webster, J., \& Stein, E. (2000). Making connections: Complementary influences on communication media choices, attitudes, and use. Organization Science, 11, 163-182.

United States Department of Labor-Bureau of Labor Statistics (2002). Work at home in 2001. Retrieved June 17, 2003, from http:// www.bls.gov/rafod/1460.pdf

Van Dyne, L., Cummings, L., \& Parks, J. M. (1995). Extra-role behaviors: In pursuit of construct and definitional clarity. In L. Cummings \& B. Staw (Eds.), Research in organizational behavior (Vol. 17, pp. 215-285). Greenwich, CT: JAI Press.

Venkatesh, A., \& Vitalari, N. (1992). An emerging distributed work arrangement: An investigation of computer-based supplemental work at home. Management Science, 38, 1687-1706.

Vroom, V. (1964). Work and motivation. New York: Wiley.

Waller, M., Conte, J., Gibson, C., \& Carpenter, M. (2001). The effect of individual perceptions of deadlines on team performance. Academy of Management Review, 26, 586-600.

Wayne, S., Shore, L., \& Liden, R. (1997). Perceived organizational support and leader member exchange: A social exchange perspective. Academy of Management Journal, 40, 82-111.

West, M., Smith, H., Lu Feng, W., \& Lawthom, R. (1998). Research excellence and departmental climate in British universities. Journal of Occupational and Organizational Psychology, 71, 261-281.

Whitely, W., Dougherty, T., \& Dreher, G. (1991). Relationships of career mentoring and socioeconomic origin to managers' and professionals' early career success. Academy of Management Journal, 34, 331-351.

Zabusky, S., \& Barley, S. (1996). Redefining success: Ethnographic observations on the careers of technicians. In P. Osterman (Ed.), Broken ladders (pp. 185-214). New York: Oxford University Press. 